\title{
Erratum to: "New Findings of Rare Fish Species in Indian and Pacific Oceans with the Description of Two New Species from the Families Gobiidae and Platycephalidae" [Journal of Ichthyology 57, 803 (2017)]
}

\author{
A. M. Prokofieva, ${ }^{a}$ \\ ${ }^{a}$ Severtsov Institute of Ecology and Evolution, Russian Academy of Science, Moscow, 119071 Russia \\ ${ }^{b}$ Shirshov Institute of Oceanology, Russian Academy of Science, Moscow, 117218 Russia \\ e-mail:prokartster@gmail.com \\ Submitted April 1, 2018; accepted for publication April 2, 2018
}

DOI: $10.1134 / \mathrm{S} 0032945218220010$

A synonymy of Cottus dybowskii with Myoxocephalus brandtii had been incorrectly indicated.

Actually this nominal species is conspecific with M. stelleri, which can be confirmed by the proportions of the head and by the variegated pattern on its ventral surface mentioned in the brief redescription of the holotype, by which the aforementioned species of sculpins can be distinguished.

The correct synonymy is the following: Cottus dybowskii Hilgendorf, $1879=$ Myoxocephalus stelleri Tilesius, 1811. 